\title{
CD20 and CD40 mediated mitogenic responses in B-lineage acute lymphoblastic leukaemia
}

\author{
Frans J. Smiers, ${ }^{1,3}$ Marleen van Paassen, ${ }^{1}$ Karel Hählen, $^{3}$ Bob Löwenberg ${ }^{1,2}$ and Ivo P. Touw ${ }^{1,2}$ \\ ${ }^{1}$ Department of Haematology, Dr Daniel den Hoed Cancer Centre, ${ }^{2}$ Institute of Haematology, Erasmus U niversity, \\ and ${ }^{3}$ Department of Haemato-Oncology, Sophia Children's Hospital, Rotterdam, The Netherlands
}

Received 27 October 1995; accepted for publication 2 January 1996

Summary Activation of $C D 20$, a cross-membrane ion
channel, induces cell cycle progression from $G_{0}$ to $G_{1}$ in $B$
lymphocytes. Subsequent activation of $C D 40$, a membrane
receptor of the nerve growth factor receptor superfamily,
transits the $B$ cells to the $S$ phase. $C D 40$ may also act
synergistically in combination with IL-4 (B lymphocytes) or
$\mathrm{IL-3/IL-7} \mathrm{(B-cell} \mathrm{precursors).} \mathrm{We} \mathrm{investigated} \mathrm{the} \mathrm{proliferative}$
responses of B-lineage acute lymphoblastic leukaemia (ALL)
cells to CD20/CD40 activation. In $18 / 56 \mathrm{ALL}$ cases, CD20 activation resulted in significant increases in DNA synthesis. Similar, although more moderate, effects were seen of activation of CD40 in 10/44 cases. Responses to CD20 or CD40 activation were independent of co-stimulation with IL-3, IL-4 or IL-7, and various cocktails of the different growth stimuli did not act synergistically.

Keywords: CD20, CD40, acute lymphoblastic leukaemia, in vitro proliferation.
B-cell development is governed by an, as yet, incomplete characterized series of haemopoietic growth factors and other stimuli. Factors that exert growth stimulatory effects on normal B-cell precursors include interleukin (IL)-3 and IL-7 (Lee et al, 1989; Namen et al, 1988; Saeland et al, 1991; Skjonsberg et al, 1991).

CD20 is a $35 / 37 \mathrm{kD}$ surface polypeptide expressed exclusively on B cells. Onset of expression of CD20 takes place before the appearance of cytoplasmic $\mu$ chains and is sustained during B-cell development until the plasma cell stage (Rosenthal et al, 1983; Stashenko et al, 1981). In normal $B$ lymphocytes, activation of CD20 proteins with the antibody $1 F 5$ induces cell cycle transition from $G_{0}$ to $G_{1}$ but is not sufficient to initiate DNA synthesis (Clark et al, 1985; Clark \& Ledbetter, 1986; Clark \& Shu, 1987; Golay et al, 1985; Smeland et al, 1985). Activation of CD20 results in its phosphorylation on serine and threonine residues (Oettgen et al, 1983; Tedder \& Schlossman, 1988) and increases the influx of $\mathrm{Ca}^{2+}$ ions into the cells. The structural and functional properties of CD20 indicate that the protein acts as a cross-membraneion channel (Bubien et al, 1993; Deans et al, 1993).

CD40, a receptor of the nerve growth factor receptor

Correspondence: Dr Ivo P. Touw, Institute of Haematology, Erasmus University Rotterdam, P.O. Box 1738, 3000 DR Rotterdam, The Netherlands. superfamily, is expressed on B cells, follicular dendritic cells, normal basal and thymic epithelium, and several carcinoma and melanoma cell lines (Clark et al, 1988; Paulie et al, 1989; Young et al, 1989). During B-cell development, the appearance of CD40 on the cell membrane precedes the expression of $\mathrm{CD} 20$ and immunoglobulin heavy chains (Uckun et al, 1990). Activation of CD40 by either the CD40 ligand or CD40 activating antibodies, in concert with IL-4, induces proliferation and maturation of $B$ lymphocytes (Banchereau et al, 1991; Crawford \& Catovsky, 1993; Defrance et al, 1992; Maliszewski et al, 1993; Spriggs et al, 1992). Also, co-activation of CD20 and CD40 results in a full mitogenic response of B lymphocytes (Gordon et al, 1987; Ledbetter et al, 1987). B-cell precursors (BCP) proliferate in response to $C D 40$ activation only when co-stimulated with IL-3, IL-7 or IL-10 (Larson \& Le Bien, 1994; Saeland et al, 1993).

Here, we show the proliferation inducing effects of CD20 and CD40 activation on B-lineage acute lymphoblastic leukaemia (ALL) cells, alone and in combination with growth factors (IL-3, IL-4 and IL-7). Activation of CD20 resulted in a proliferative response of ALL cells in 18/58 $(31 \%)$ cases; activation of CD40 induced DNA synthesis in $10 / 44(23 \%)$ cases. With the exception of one case, no synergistic effects of the various stimuli were seen. These data show that responses of $A L L$ cells to CD20/CD40 activation are heterogenous and distinct from those of normal (pre-)B cells. 


\section{Frans J. Smiers et al}

\section{MATERIALS AND METHODS}

Isolation of cells. ALL cells were isolated from bone marrow or peripheral blood by Ficoll-Hypaque (Nygaard, Oslo, Norway), density gradient centrifugation as described previously (Touw et al, 1989). T cells were removed from the A LL cell samples by E-rosette formation using 2-aminoethylisothiouronium bromide (AET) treated sheep erythrocytes, followed by sedimentation through Ficoll-Hypaque (Madsen et al, 1980). Monocytes were removed by adherence to plastic petri dishes at $37^{\circ} \mathrm{C}$ for $1 \mathrm{~h}$. In all cases informed consent was obtained. The ALL cell samples were subjected to routine diagnostic immunophenotyping with a panel of monoclonal antibodies $(M \circ A b)$. Six cases were classified as null-ALL (patients 1-6), 36 as common-ALL (patients 7-41, 58), 11 as pre-B-ALL (patients 42-52) and five as B-ALL (patients 53-57) according to established criteria (van Dongen et al, 1988). Cells were used either fresh or after cryopreservation using a controlled-freezing apparatus (Planer Biomed, Sunbury-on-Thames) (Touw et al, 1989).

Enriched fractions of normal peripheral blood B-lymphocytes were obtained using the same protocol.

DNA synthesis assay. DNA synthesis was assessed by uptake of ${ }^{3} \mathrm{H}$-thymidine $\left({ }^{3} \mathrm{H}-\mathrm{TdR}\right.$, specific activity $2 \mathrm{Ci} / \mathrm{mmol}$, Amersham International, Amersham) as described (Delwel et al, 1988). In brief, $0.2 \times 10^{5}$ cells were cultured in triplicate in 96-well dishes (Greiner, Alphen a/d Rijn, The Netherlands) for 3 and $7 \mathrm{~d}$ in $100 \mu \mathrm{l}$ serum-free medium (Touw et al, 1990). $18 \mathrm{~h}$ before harvesting on nitrocellulose filters using a Titertek cell harvester (Flow Laboratories, Irvine) $0.1 \mu \mathrm{Ci}{ }^{3} \mathrm{H}-\mathrm{TdR}$ was added to each well. ${ }^{3} \mathrm{H}-\mathrm{TdR}$ incorporation was measured by liquid scintillation counting.

Growth factors and CD20 or CD40 activating antibodies. Human IL-3 (Gist Brocades, Delft, The Netherlands) was used at $100 \mathrm{U} / \mathrm{ml}$; human IL-4 (Dr S. Clark, Genetics Institute Cambridge, Mass.) was added to the cultures at a 1:5000 dilution of COS cell supernatant; human IL-7 (Dr L. Park,
Immunex Corp., Seattle, Wash.) was used at $100 \mathrm{U} / \mathrm{ml}$. AntiCD40 monoclonal antibody (MoAb) 14G7, provided by Dr R. A. W. van Lier (Central Laboratory of the Red Cross Blood Transfusion Service, Amsterdam) was used at a $1: 250$ dilution of ascites. The CD20 activating MoAb 1F5 (Clark \& Ledbetter, 1986; Clark et al, 1985) (Dr E. A. Clark, University of Washington, Seattle, Wash.) was used at a final concentration of $3 \mu \mathrm{g} / \mathrm{ml}$.

Analysis of CD20 and CD40 expression. Expression of CD20 or CD40 was assessed by flow cytometry (FACScan) after labelling of cells with either anti CD20 MoAb 1F5 (Clark et al, 1985 ) or the anti-CD40 MoAb 14 G7 and goat anti-mouse immunoglobulin coupled to fluorescein isothiocyanate (GAM/FITC, Nordic Tilburg, The Netherlands).

\section{RESULTS AND DISCUSSION}

\section{CD20 activation of ALL cells}

Dose titration experiments performed with ALL cells from four patients indicated that maximal stimulation of DNA synthesis is seen at $1 \mathrm{~F} 5$ concentrations of $1-10 \mu \mathrm{g} / \mathrm{ml}$. A representative experiment is shown in Fig $1 \mathrm{~A}$. Parallel incubations with control MoAb did not result in mitogenic responses (data not shown). Proliferative responses to $1 \mathrm{~F} 5(3 \mu \mathrm{g} / \mathrm{ml})$ were analysed in 58 cases of ALL. CD20 activation resulted in a significant increase of DNA synthesis in 18 cases (Table I). The (in)ability to induce DNA synthesis of 1F5 did not correlate with the immunologic subtype of ALL. Therefore differences of maturation phenotype of ALL did not explain the heterogeneity in responses to $\mathrm{CD} 20$ activation. A correlation was neither apparent between responses to CD20 activation nor responses to IL-3 or IL-7 (Fig 2). In fact, the ran dom distribution of the plotted stimulation indices indicates that each of the individual responses is independent from any of the responses to the other growth stimuli. As expected, flow cytrometric analysis with anti-CD20 showed

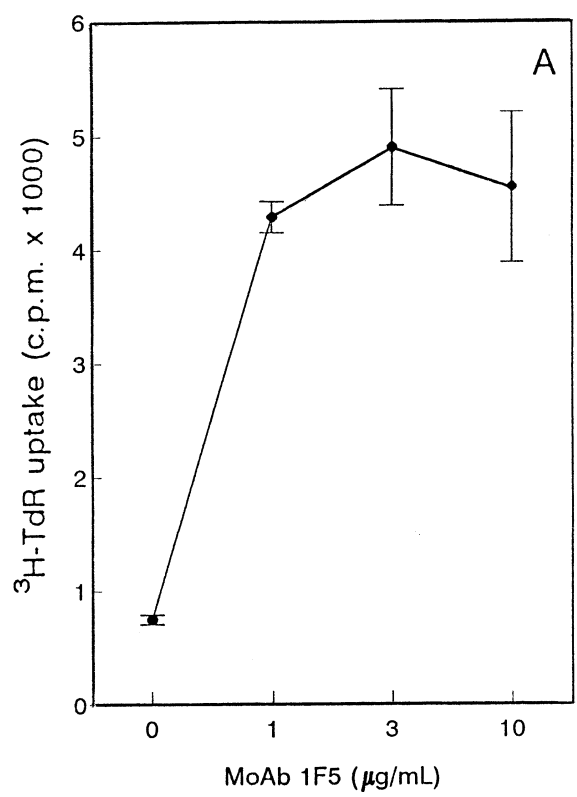

MoAb $1 F 5(\mu \mathrm{g} / \mathrm{mL})$

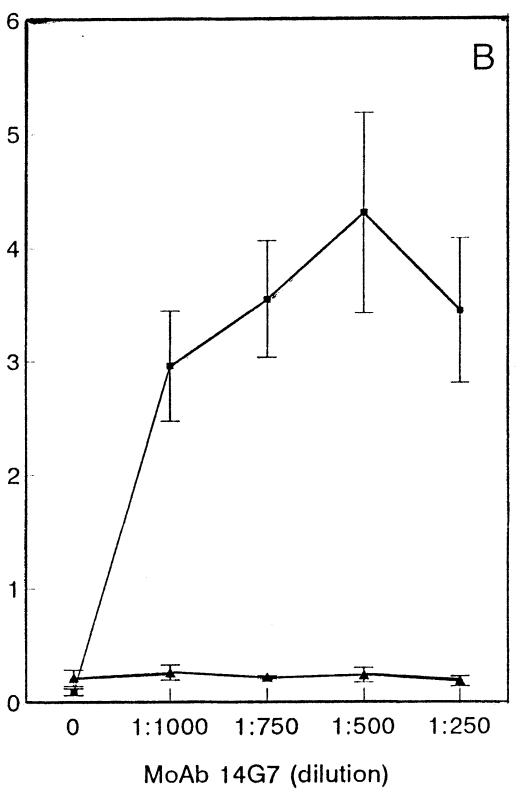

Fig 1. (A) Response of human BCP-ALL cells to titrated doses of the CD2 0 activating M OA b $1 F 5$ in a ${ }^{3} \mathrm{H}-\mathrm{TdR}$ uptake assay. (B) Response of peripheral $B$ cells to serial dilutions of the activating CD40 MoAb $14 \mathrm{G} 7$ in a ${ }^{3} \mathrm{H}-\mathrm{TdR}$ uptake assay in the presence (squares) or absence (triangles) of IL-4. 
Table I. Proliferative responses of ALL cells to activation of CD20 in comparison to responses to IL-3 or IL-7.*

\begin{tabular}{|c|c|c|c|c|c|c|}
\hline Pt & $\begin{array}{l}\text { ALL } \\
\text { subtype }\end{array}$ & $\begin{array}{l}\text { No additive } \\
\text { to culture }\end{array}$ & Anti-CD20 & IL-3 & IL-7 & Irradiated cellsł \\
\hline 1 & Null & $1.3 \pm 0.6 \dagger$ & $10 \cdot 9 \pm 1 \cdot 7$ & $3 \cdot 7 \pm 1 \cdot 8$ & $2 \cdot 4 \pm 0.4$ & $0.4 \pm 0.1$ \\
\hline 6 & Null & $10 \cdot 7 \pm 0 \cdot 2$ & $25 \cdot 2 \pm 6 \cdot 5$ & $50 \cdot 8 \pm 7 \cdot 6$ & $18 \cdot 0 \pm 1 \cdot 2$ & $0.7 \pm 0.1$ \\
\hline 10 & Common & $18 \cdot 4 \pm 0.6$ & $29.8 \pm 0.9$ & $31 \cdot 8 \pm 1 \cdot 0$ & $22 \cdot 4 \pm 2 \cdot 0$ & $0.4 \pm 0.1$ \\
\hline 13 & Common & $8.8 \pm 0.2$ & $59 \cdot 1 \pm 1 \cdot 6$ & $18 \cdot 4 \pm 1 \cdot 3$ & $17 \cdot 1 \pm 1 \cdot 7$ & $0.6 \pm 0.1$ \\
\hline 15 & Common & $13 \cdot 0 \pm 0.8$ & $55 \cdot 5 \pm 5 \cdot 5$ & $23 \cdot 3 \pm 3 \cdot 0$ & $20 \cdot 3 \pm 1 \cdot 0$ & $0.2 \pm 0.0$ \\
\hline 16 & Common & $13.4 \pm 0.9$ & $20 \cdot 6 \pm 3 \cdot 1$ & n.d.§ & $17 \cdot 2 \pm 1 \cdot 0$ & $0.2 \pm 0.0$ \\
\hline 22 & Common & $3 \cdot 8 \pm 0 \cdot 1$ & $9 \cdot 3 \pm 2 \cdot 1$ & $18 \cdot 4 \pm 4 \cdot 2$ & $6 \cdot 3 \pm 0.5$ & $0.4 \pm 0.2$ \\
\hline 30 & Common & $5 \cdot 9 \pm 0 \cdot 2$ & $65 \cdot 9 \pm 11$ & $11 \cdot 4 \pm 2 \cdot 2$ & $10 \cdot 1 \pm 1 \cdot 8$ & $0.7 \pm 0.2$ \\
\hline 31 & Common & $5.9 \pm 0.5$ & $78 \cdot 2 \pm 7 \cdot 2$ & $20 \cdot 0 \pm 2 \cdot 1$ & $27 \cdot 3 \pm 3 \cdot 5$ & $0.5 \pm 0.2$ \\
\hline 32 & Common & $3 \cdot 1 \pm 0 \cdot 3$ & $8 \cdot 1 \pm 2 \cdot 2$ & $14 \cdot 8 \pm 4 \cdot 6$ & $18 \cdot 2 \pm 0.4$ & $0.3 \pm 0.1$ \\
\hline 36 & Common & $2 \cdot 6 \pm 0 \cdot 4$ & $13 \cdot 1 \pm 2 \cdot 3$ & $6 \cdot 6 \pm 2 \cdot 0$ & $2 \cdot 3 \pm 0.6$ & $0.7 \pm 0.1$ \\
\hline 58 & Common & $7 \cdot 9 \pm 1 \cdot 3$ & $27 \cdot 0 \pm 2 \cdot 7$ & $9 \cdot 8 \pm 2 \cdot 7$ & $6 \cdot 4 \pm 1 \cdot 1$ & $0.3 \pm 0.1$ \\
\hline 38 & Common & $7 \cdot 1 \pm 2 \cdot 2$ & $14 \cdot 7 \pm 3 \cdot 3$ & $21 \cdot 0 \pm 6 \cdot 9$ & $10 \cdot 3 \pm 1.9$ & $1.4 \pm 0.2$ \\
\hline 43 & Pre-B & $10 \cdot 5 \pm 1.8$ & $23 \cdot 3 \pm 6 \cdot 0$ & $18 \cdot 9 \pm 5 \cdot 1$ & $19 \cdot 1 \pm 1 \cdot 4$ & $1.0 \pm 0.0$ \\
\hline 44 & Pre-B & $29 \cdot 6 \pm 1 \cdot 9$ & $87 \cdot 3 \pm 9 \cdot 7$ & $58 \cdot 1 \pm 10$ & $69 \cdot 3 \pm 3 \cdot 0$ & $0.3 \pm 0.2$ \\
\hline 45 & Pre-B & $19 \cdot 3 \pm 1 \cdot 0$ & $39 \cdot 0 \pm 8 \cdot 0$ & $27 \cdot 5 \pm 1 \cdot 4$ & $31 \cdot 0 \pm 3 \cdot 4$ & $0.3 \pm 0.2$ \\
\hline 50 & Pre-B & $2 \cdot 2 \pm 0.6$ & $24 \cdot 9 \pm 1 \cdot 0$ & $6 \cdot 6 \pm 1 \cdot 4$ & $2 \cdot 2 \pm 0 \cdot 4$ & $0.4 \pm 0.1$ \\
\hline 57 & B & $19 \cdot 4 \pm 1 \cdot 8$ & $32 \cdot 0 \pm 1 \cdot 0$ & $273 \pm 14 \cdot 7$ & $19 \cdot 6 \pm 6 \cdot 0$ & $0.9 \pm 0.2$ \\
\hline
\end{tabular}

\footnotetext{
* Only cases responsive to CD20 activation have been included. In these cases, stimulation values (1F5 supplemented versus non-supplemented controls) were $>1 \cdot 5$.

† Data are from ${ }^{3} \mathrm{H}$-thymidine uptake assays and are expressed as mean counts per minute $\times 100 \pm$ standard deviation of triplicate cultures.

$\ddagger$ Cells were irradiated ( $25 \mathrm{~Gy}$ ) before culture

$\S$ Not determined.
}

that ALL cells of $1 F 5$ responding cases expressed CD20. In 15/27 1F5 nonresponders analysed, the ALL cells expressed $\mathrm{CD} 20$, indicating that in these cases the absence of response to 1 F5 was not caused by lack of CD20.
CD40 activation of $A L L$ cells

In dose titration experiments, maximal stimulation of DNA synthesis by CD40 activating antibody $14 \mathrm{G} 7$ was reached at dilutions of $1: 1000-1: 250$ (Fig 1B). In 10/44 ALL cases,

Table II. Proliferative response of ALL cells to activation of CD40 in comparison to responses to IL-3, IL-7 and CD20 activation.*

\begin{tabular}{|c|c|c|c|c|c|c|c|}
\hline Pt & $\begin{array}{l}\text { ALL } \\
\text { subtype }\end{array}$ & $\begin{array}{l}\text { No additive } \\
\text { to culture }\end{array}$ & Anti-CD40 & IL-3 & IL7 & Anti-CD20 & $\begin{array}{l}\text { Irradiated } \\
\text { cellsł }\end{array}$ \\
\hline 1 & Null & $1.3 \pm 0.6 \dagger$ & $9 \cdot 6 \pm 2 \cdot 4$ & $3 \cdot 7 \pm 1 \cdot 8$ & $2 \cdot 4 \pm 0.5$ & $10 \cdot 9 \pm 1 \cdot 7$ & $0.4 \pm 0.1$ \\
\hline 11 & Null & $35 \cdot 4 \pm 1.5$ & $70 \cdot 8 \pm 3 \cdot 1$ & $121 \pm 4$ & $33.5 \pm 0.2$ & $35 \cdot 8 \pm 1 \cdot 4$ & $0.4 \pm 0.1$ \\
\hline 8 & Common & $349 \pm 22$ & $568 \pm 45$ & $341 \pm 8$ & $336 \pm 12$ & $389 \pm 8$ & $0.6 \pm 0.1$ \\
\hline 14 & Common & $5.5 \pm 0.9$ & $15 \cdot 6 \pm 3 \cdot 6$ & $15 \cdot 0 \pm 2 \cdot 0$ & $5.9 \pm 1.6$ & $3 \cdot 8 \pm 1 \cdot 2$ & $0.4 \pm 0.1$ \\
\hline 21 & Common & $5.6 \pm 0.6$ & $32 \cdot 3 \pm 1 \cdot 3$ & $16 \cdot 8 \pm 1.9$ & $12 \cdot 2 \pm 1 \cdot 5$ & $8 \cdot 9 \pm 1 \cdot 2$ & $0.2 \pm 0.1$ \\
\hline 26 & Common & $31 \cdot 5 \pm 1 \cdot 0$ & $45 \cdot 5 \pm 3 \cdot 9$ & $35 \cdot 2 \pm 1 \cdot 6$ & $27 \cdot 0 \pm 1 \cdot 7$ & $32 \cdot 9 \pm 0.4$ & $1.4 \pm 0.2$ \\
\hline 30 & Common & $5.9 \pm 0.2$ & $12 \cdot 4 \pm 1.9$ & $11 \cdot 4 \pm 2 \cdot 1$ & $10 \cdot 1 \pm 1 \cdot 8$ & $65.9 \pm 11$ & $0.7 \pm 0.2$ \\
\hline 48 & Pre-B & $17 \cdot 6 \pm 3 \cdot 9$ & $28.9 \pm 0.8$ & $25 \cdot 7 \pm 1 \cdot 1$ & $10 \cdot 7 \pm 4 \cdot 0$ & $19 \cdot 8 \pm 1 \cdot 2$ & $0.4 \pm 0.1$ \\
\hline 50 & Pre-B & $2.2 \pm 0.6$ & $5 \cdot 5 \pm 0 \cdot 2$ & $6 \cdot 5 \pm 1 \cdot 4$ & $2 \cdot 2 \pm 0.4$ & $24 \cdot 9 \pm 1 \cdot 0$ & $0.3 \pm 0.1$ \\
\hline 52 & Pre-B & $3.2 \pm 0.0$ & $8.0 \pm 0.6$ & $16 \cdot 2 \pm 2 \cdot 3$ & $2.0 \pm 0.4$ & $3 \cdot 6 \pm 1 \cdot 3$ & $0.6 \pm 0.1$ \\
\hline 55 & B & $1.8 \pm 0.0$ & $5.0 \pm 0.3$ & $1.8 \pm 0.5$ & $2.0 \pm 0.2$ & $1.9 \pm 0.3$ & $0.4 \pm 0.1$ \\
\hline
\end{tabular}

* Only cases responsive to CD40 activation have been included. In these cases, stimulation values (14G7 supplemented versus nonsupplemented controls) were $>1.5$

$\dagger$ Data are from ${ }^{3} \mathrm{H}$-thymidine uptake assays and are expressed as mean counts per minute $\times 100 \pm$ standard deviation of triplicate cultures.

‡ Cells were irradiated (25 Gy) before culture. 
128 Frans J. Smiers et al

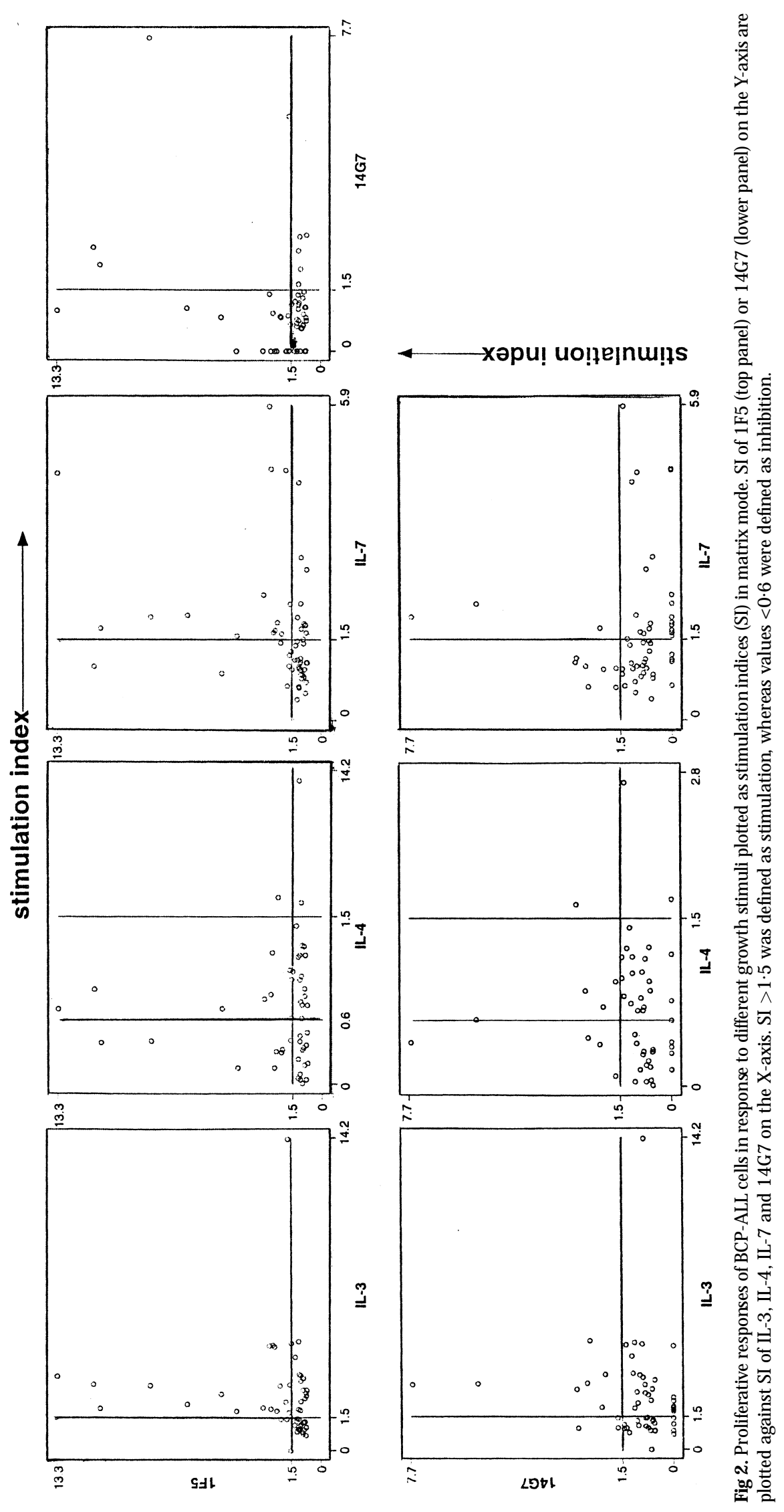

(C) 1996 Blackwell Science Ltd, British Journal of Haematology 93: 125-130 
DNA synthesis was moderately enhanced by $14 \mathrm{G} 7(1: 250$ dilution, Table II).

Previously, Law et al (1990) could not demonstrate mitogenic effects of CD40 activation in ALL cells. However, the latter study was based on the analysis of eight cases of ALL only (Law et al, 1990). The various immunological subtypes of B-cell ALL were represented among the $10 \quad 14 \mathrm{G} 7$ responsive cases. No correlation was apparent between responses to anti-CD40 and those to IL-3, IL-4, IL-7 or antiCD20 (Fig 2). All 14G7 responders expressed CD40 at levels detectable by flow cytometry. In 6/8 14G7 nonresponders, ALL cells expressed CD40, suggesting that in the majority of cases non-responsiveness of ALL cells following CD40 stimulation is due to ineffective signalling.

Activation of $\mathrm{CD} 20$ and CD40 in combination with other stimuli Certain stimuli act synergistically in inducing proliferative responses in nonleukaemic (pre-)B cells. Particularly, this has been demonstrated for the combined activation of CD20 and CD40 (Gordon et al, 1987; Ledbetter et al, 1987), and for activation of CD40 in combination with IL-4 (Banchereau et al, 1991; Defrance et al, 1992; Maliszewski et al, 1993; Spriggs et al, 1992), IL-3 or IL-7 (Saeland et al, 1993). Proliferative responses of ALL cells to different combinations of stimuli, in the context of activation of CD20 or CD40, are summarized in Table III. Although additive effects (1F5 + IL-3; 1F5 + IL-7; 1F5 + 14G7) were occasionally seen, none of the combinations tested were synergistic, except in a single case of ALL in which both the combinations

Table III. Summary of proliferative responses of ALL cells to different stimuli.

\begin{tabular}{|c|c|c|}
\hline Stimulus & $\begin{array}{l}\text { Frequency of } \\
\text { response (\%) }\end{array}$ & Type of response \\
\hline IL-3 & $31 / 58(53 \%)$ & Stimulation \\
\hline IL-7 & $24 / 58(41 \%)$ & Stimulation \\
\hline IL-4 & $\begin{array}{c}2 / 49(4 \%) \\
22 / 49(45 \%)\end{array}$ & $\begin{array}{l}\text { Stimulation } \\
\text { Inhibition }\end{array}$ \\
\hline MoAb 1F5 (CD20 & $18 / 58(31 \%)$ & Stimulation \\
\hline Moab 14G7 (CD40 & $18 / 38(31 \%)$ & \\
\hline activation) & $10 / 44(23 \%)$ & Stimulation \\
\hline $1 F 5+I L-3$ & $22 / 36(61 \%)$ & $\begin{array}{l}\text { Additive response in } \\
\text { four cases; no synergy }\end{array}$ \\
\hline $1 F 5+I L-7$ & $25 / 50(50 \%)$ & $\begin{array}{l}\text { A dditive response in } \\
\text { nine cases; no synergy }\end{array}$ \\
\hline $1 \mathrm{~F} 5+14 \mathrm{G} 7$ & $22 / 36(61 \%)$ & $\begin{array}{l}\text { A dditive response in } \\
\text { five cases; no synergy }\end{array}$ \\
\hline $14 \mathrm{G} 7+\mathrm{IL}-3$ & $6 / 12(50 \%)$ & $\begin{array}{l}\text { Synergistic response in } \\
\text { one case }\end{array}$ \\
\hline $14 \mathrm{G} 7+\mathrm{IL}-7$ & $5 / 12(42 \%)$ & $\begin{array}{l}\text { Additive response in } \\
\text { two cases; synergistic } \\
\text { response in one case }\end{array}$ \\
\hline \multirow[t]{2}{*}{$14 \mathrm{G} 7+\mathrm{IL}-4$} & $2 / 11(18 \%)$ & $\begin{array}{l}\text { Stimulation; } \\
\text { no additive or } \\
\text { synergistic responses }\end{array}$ \\
\hline & $5 / 11(45 \%)$ & Inhibition \\
\hline
\end{tabular}

Activation of CD20 and CD40 in B-lineage ALL 129

14G7 + IL-3 and 14G7 + IL-7 synergistically stimulated DNA synthesis.

The response of ALL cells to activation of CD20 or CD40, with or without the addition of cytokines, differ from those of nonleukaemic (pre-)B cells. Whether this would indicate that ALL cells generally display aberrant responses to CD20 and CD40 activation is not clear. In normal B lymphocytes activation of CD20 induces transition from G0 to G1 (Clark \& Ledbetter, 1986; Clark et al, 1985; Golay et al, 1985; Smeland et al, 1985), whereas CD40 activation promotes the transition from G1 to S phase of the cell cycle. A ctivation of both of these molecules is required for transduction of a full mitogenic signal (Golay et al, 1991; Gordon et al, 1987; Ledbetter et al, 1987). The observation that in certain cases ALL cells proliferate in response to either CD20 or CD40 activation as a single growth stimulus could be suggestive of a partial loss of cell cycle control bypassing the necessity of cooperation of signals for a mitogenic response. Further elucidation of signalling properties of CD20 and CD40 in normal and leukaemic (pre-)B cells is needed to clarify these issues.

\section{ACKNOW LEDGMENTS}

This work was supported by the Dutch Cancer Society and the Pediatric Oncology Foundation Rotterdam. We thank J. W. B. Moll for assistance with data analysis.

\section{REFERENCES}

Banchereau, J., de Paoli, P., Valle, A., Garcia, E. \& Rousset, F. (1991) Long-term human B-cell lines dependent on interleukin-4 and antibody to CD40. Science, 251, 70-72.

Bubien, J.K., Zhou, L.J., Bell, P.D., Frizzell, R.A. \& Tedder, T.F. (1993) Transfection of the CD20 cell surface molecule into ectopic cell types generates a $\mathrm{Ca}^{2+}$ conductance found constitutively in $\mathrm{B}$ lymphocytes. Journal of Cellular Biology, 121, 1121-1132.

Clark, E.A. \& Ledbetter, J.A. (1986) Activation of human B cells mediated through two distinct cell surface differentiation antigens, $\mathrm{Bp} 35$ and Bp50. Proceedings of the $\mathrm{N}$ ational A cademy of Science of the United States of America, 83, 4494-4498.

Clark, E.A. \& Shu, G. (1987) Activation of human B cell proliferation through surface Bp35 (CD20) polypeptides or immunoglobulin receptors. Journal of Immunology, 138, 720-725.

Clark, E.A., Shu, G. \& Ledbetter, J.A. (1985) Role of the Bp35 cell surface polypeptide in human B-cell activation. Proceedings of the National Academy of Sciences of the United States of America, 82, $1766-1770$.

Clark, E.A., Yip, T.C., Ledbetter, J.A., Yukawa, H., Kikutani, H., Kishimoto, T. \& Ng, M.H. (1988) CDw40 and BLCa-specific monoclonal antibodies detect two distinct molecules which transmit progression signals to human B lymphocytes. European Journal of Immunology, 18, 451-457.

Crawford, D.H. \& Catovsky, D. (1993) In vitro activation of leukaemic B cells by interleukin-4 and antibodies to CD40. Immunology, 80, 40-44.

Deans, J.P., Schieven, G.L., Shu, G.L., Valentine, M.A., Gilliland, L.A., Aruffo, A., Clark, E.A. \& Ledbetter, J.A. (1993) Association of tyrosine and serine kinases with the B cell surface antigen CD20. Induction via CD20 of tyrosine phosphorylation and activation of phospholipase C-gamma 1 and PLC phospholipase C-gamma 2. Journal of Immunology, 151, 4494-4504.

Defrance, T., Vanbervliet, B., Durand, I., Briolay, J. \& Banchereau, J. 


\section{Frans J. Smiers et al}

(1992) Proliferation and differentiation of human $\mathrm{CD}^{+}$and $\mathrm{CD}^{-}$ $B$ cell subsets activated through their antigen receptors or CD40 antigens. European Journal of Immunology, 22, 2831-2839.

Delwel, R., Salem, M., Pellens, C., Dorssers, L., Wagemaker, G., Clark, S. \& Lowenberg, B. (1988) Growth regulation of human acute myeloid leukemia: effects of five recombinant hematopoietic factors in a serum-free culture system. Blood, 72, 1944-1949.

Golay, J., Capucci, A., Arsura, M., Castellano, M., Rizzo, V. \& Introna, M. (1991) Expression of c-myb and B-myb, but not A-myb, correlates with proliferation in human hematopoietic cells. Blood, 77, 149-158.

Golay, J.T., Clark, E.A. \& Beverley, P.C. (1985) The CD20 (Bp35) antigen is involved in activation of $B$ cells from the $G 0$ to the $G 1$ phase of the cell cycle. Journal of Immunology, 135, 3795-3801.

Gordon, J., Millsum, M.J., Guy, G.R. \& Ledbetter, J.A. (1987) Synergistic interaction between interleukin 4 and anti-Bp50 (CDw40) revealed in a novel $B$ cell restimulation assay. European Journal of Immunology, 17, 1535-1538.

Larson, A.W. \& LeBien, T.W. (1994) Cross-linking CD40 on human B cell precursors inhibits or enhances growth depending on the stage of development and the IL costimulus. Journal of Immunology, 153, 584-594.

Law, C.L., Wormann, B. \& LeBien, T.W. (1990) Analysis of expression and function of CD40 on normal and leukemic human B cell precursors. Leukemia, 4, 732-738.

Ledbetter, J.A., Shu, G., Gallagher, M. \& Clark, E.A. (1987) Augmentation of normal and malignant $B$ cell proliferation by monoclonal antibody to the B cell-specific antigen BP50 (CDW 40). Journal of Immunology, 138, 788-794.

Lee, G., Namen, A.E., Gillis, S., Ellingsworth, L.R. \& Kincade, P.W. (1989) Normal B cell precursors responsive to recombinant murine IL-7 and inhibition of IL-7 activity by transforming growth factorbeta. Journal of Immunology, 142, 3875-3883.

Madsen, M., Johnsen, H.E., Hansen, P.W. \& Christiansen, S.E. (1980) Isolation of human $\mathrm{T}$ and $\mathrm{B}$ lymphocytes by E-rosette gradient centrifugation: characterization of the isolated subpopulations. Journal of Immunological M ethods, 33, 323-336.

Maliszewski, C.R., Grabstein, K., Fanslow, W.C., Armitage, R., Spriggs, M.K. \& Sato, T.A . (1993) Recombinant CD40 ligand stimulation of murine $B$ cell growth and differentiation: cooperative effects of cytokines. European Journal of Immunology, 23, 1044-1049.

Namen, A.E., Lupton, S., Hjerrild, K., Wignall, J., Mochizuki, D.Y., Schmierer, A., Mosley, B., March, C.J., Urdal, D. \& Gillis, S. (1988) Stimulation of B-cell progenitors by cloned murine interleukin-7. Nature, 333, 571-573.

Oettgen, H.C., Bayard, P.J., Van Ewijk, W., Nadler, L.M \& \& Terhorst, C.P. (1983) Further biochemical studies of the human B-cell differentiation antigens B1 and B2. Hybridoma, 2, 17-28.

Paulie, S., Rosen, A., Ehlin-Henriksson, B., Braesch-Andersen, S., Jakobson, E., Koho, H. \& Perlmann, P. (1989) The human B lymphocyte and carcinoma antigen, CDw40, is a phosphoprotein involved in growth signal transduction. Journal of I mmunology, $\mathbf{1 4 2}$ 590-595.

Rosenthal, P., Rimm, I.J., Umiel, T., Griffin, J.D., Osathanondh, R.,
Schlossman, S.F. \& Nadler, L.M. (1983) Ontogeny of human hematopoietic cells: analysis utilizing monoclonal antibodies Journal of Immunology, 131, 232-237.

Saeland, S., Duvert, V., Moreau, I. \& Banchereau, J. (1993) Human B cell precursors proliferate and express CD23 after CD40 ligation. Journal of Experimental M edicine, 178, 113-20.

Saeland, S., Duvert, V., Pandrau, D., Caux, C., Durand, I., Wrighton, N., Wideman, J., Lee, F. \& Banchereau, J. (1991) Interleukin-7 induces the proliferation of normal human B-cell precursors. Blood, 78, 2229-2238.

Skjonsberg, C., Erikstein, B.K., Smeland, E.B., Lie, S.O., Funderud, S., Beiske, K. \& Blomhoff, H.K. (1991) Interleukin-7 differentiates a subgroup of acute lymphoblastic leukemias. Blood, 77, 24452450

Smeland, E., Godal, T., Ruud, E., Beiske, K., Funderud, S., Clark, E.A., Pfeifer-Ohlsson, S. \& Ohlsson, R. (1985) The specific induction of myc protooncogene expression in normal human $B$ cells is not a sufficient event for acquisition of competence to proliferate Proceedings of the $\mathrm{N}$ ational Academy of Sciences of the United States of America, 82, 6255-6259.

Spriggs, M.K., Armitage, R.J., Strockbine, L., Clifford, K.N., Macduff, B.M., Sato, T.A., Maliszewski, C.R. \& Fanslow, W.C. (1992) Recombinant human CD40 ligand stimulates $B$ cell proliferation and immunoglobulin E secretion. Journal of Experimental M edicine, 176, 1543-1550.

Stashenko, P., Nadler, L.M., Hardy, R. \& Schlossman, S.F. (1981) Expression of cell surface markers after human $B$ lymphocyte activation. Proceedings of the National Academy of Sciences of the United States of America, 78, 3848-3852.

Tedder, T.F. \& Schlossman, S.F. (1988) Phosphorylation of the B1 (CD20) molecule by normal and malignant human B lymphocytes. Journal of Biological Chemistry, 263, 10009-10015.

Touw, I., Groot-Loonen, J., Broeders, L., van A gthoven, T., Hählen, K., Hagemeijer, A \& \& Löwenberg, B. (1989) Recombinant hematopoietic growth factors fail to inducea proliferative responsein precursor B acute lymphoblastic leukemia. Leukemia, 3, 356-362.

Touw, I., Pouwels, K., van Agthoven, T., van Gurp, R., Budel, L., Hoogerbrugge, H., Delwel, R., Goodwin, R., Namen, A. \& Löwenberg, B. (1990) Interleukin-7 is a growth factor of precursor $B$ and T acute lymphoblastic leukemia. Blood, 75, 2097-2101.

Uckun, F.M., Gajl-Peczalska, K., Myers, D.E., Jaszcz, W., Haissig, S. \& Ledbetter, J.A. (1990) Temporal association of CD40 antigen expression with discrete stages of human B-cell ontogeny and the efficacy of anti-CD40 immunotoxins against clonogenic B-lineage acute lymphoblastic leukemia as well as B-lineage non-Hodgkin's lymphoma cells. Blood, 76, 2449-2456.

van Dongen, J.J., A driaansen, H.J. \& Hooijkaas, H. (1988) Immunophenotyping of leukaemias and non-Hodgkin's lymphomas. Immunological markers and their CD codes. Netherlands Journal of M edicine, 33, 298-314

Young, L.S., Dawson, C.W., Brown, K.W. \& Rickinson, A.B. (1989) Identification of a human epithelial cell surface protein sharing an epitope with the C3d/Epstein-Barr virus receptor molecule of $B$ lymphocytes. International Journal of Cancer, 43, 786-794. 